\title{
Modelling Crude Oil Price Volatility and the Effects of Global Financial Crisis
}

\author{
Mert URAL, Department of Economics, Faculty of Economics and Administrative Sciences, Dokuz Eylul
} University, Turkey; e-mail: mert.ural@deu.edu.tr

\section{Ham Petrol Fiyat Oynaklığı Modellemesi ve Küresel Finansal Krizin Etkileri}

\begin{abstract}
In recent years and global financial crisis period, oil prices are characterized by high volatilities. The aim of this paper is to evaluate the comparative performance of volatility models and to reveal the effects of global financial crisis on volatility by using daily returns of crude oil prices. According to the sample periods, the results of models highlight that APGARCH and FIAPGARCH models with Student-t and Skewed Student-t distributions best fit oil prices. Furthermore, when considering the global financial crisis, the results show that the crude oil prices are characterized by high volatilities and have long memory effects, as expected.

Keywords : Crude Oil, Volatility, Asymmetry, Long Memory.

JEL Classification Codes : $\quad$ C22, C52, Q43.

\section{$\ddot{\mathbf{O z}}$}

Son yıllarda ve küresel finansal kriz döneminde, petrol fiyatları yüksek oynaklık düzeyleriyle nitelendirilmektedir. Bu çalışmanın amacı, ham petrol fiyatlarının günlük getirilerini kullanarak oynaklık modellerinin karşılaştırmalı performansını değerlendirmek ve küresel krizin oynaklık üzerindeki etkisini incelemektir. Farklı örneklem dönemleri dikkate alındığında, modellerin tahmin sonuçları petrol fiyatlarının en uygun biçimde Student-t ve Çarpık Student-t dağılımlı APGARCH ve FIAPGARCH modelleriyle yorumlandığını vurgulamaktadır. Ayrıca, küresel finansal kriz göz önüne alındığında sonuçlar, beklendiği gibi ham petrol fiyatlarının yüksek oynaklıklarla nitelendirildiğini ve uzun hafiza etkilerine sahip olduğunu göstermektedir.
\end{abstract}

Anahtar Sözcükler $\quad$ : Ham Petrol, Oynaklık, Asimetri, Uzun Hafiza. 


\section{Introduction}

The global oil market is the most important of the world energy markets because of oil's dominant role as an energy source. Crude oil prices determined by supply and demand factors on a worldwide basis. Reflecting the status of oil as the most globalized commodity, crude oil prices have exhibited greater levels of volatility than other commodities and asset prices from a historical perspective.

Dependency on oil-derived fuels in various sectors has left the global economy vulnerable to several macroeconomic effects of the oil price volatility. Three primary macroeconomic variables: consumption, investment, and industrial production are affected by two factors: the degree of uncertainty generated by oil price volatility; and the behavior of economic agents to uncertainty. The impact of the oil price volatility on consumer, investor, and producer behavior, strongly influences both the level of inflation and unemployment within oil dependent economies (Federer, 1996; Castillo et.al., 2010).

As the oil price fluctuates, different types of national economy are affected in different ways. Oil-importing (consuming) countries will benefit the most from low oil prices, whereas oil-exporting (producing) countries will be negatively impacted. Oil price increase causes to a transfer of income from oil importing to oil-exporting countries through a shift with trade relations (International Energy Agency, 2004: 13-4).

There are periods of time when the price of crude oil is relatively stable and other periods of time when the price can become volatile. The figure below shows the crude oil price movements since 1970. As seen on figure 1, crude oil prices react to a variety of geopolitical and economic events.

The oil crisis of 1970's was a milestone for oil markets and economies. After this crisis, crude oil prices have been subject to notable volatility. 1980's was more impassive after 1970's crisis period. However, by 1990's the prices started to rise especially because of Gulf War (Iraq invades Kuwait). The fluctuation process continued through the end of 1990's (UNDP/ESMAP, 2002: 5). Particularly by 2003 world oil market was characterized by high oil demand growth. In October 2004, because of the Iraq War and politic tensions, the oil price increases were at their yearly peak with $\$ 53$ per barrel. As a result of these price increases, consumers' budgets have been under pressure, business costs have risen, and oil producers' profits have increased (Pirog, 2005: 4-6). In the middle of the year 2008, crude oil price rose unceasingly and up to a record high price, nearly $\$ 140$ per barrel. However, in the second half of the year 2008 it dropped rapidly at the lowest level to $\$ 40$ per barrel. This large oil price fluctuation tendency has continued in recent years (Kojima, 2009: 1; Yan, 2012: 41; Le, 2015: 1). 


\section{Figure: 1}

\section{Daily Price of West Texas Intermediate (WTI) Crude Oil Market (1970-2015)}

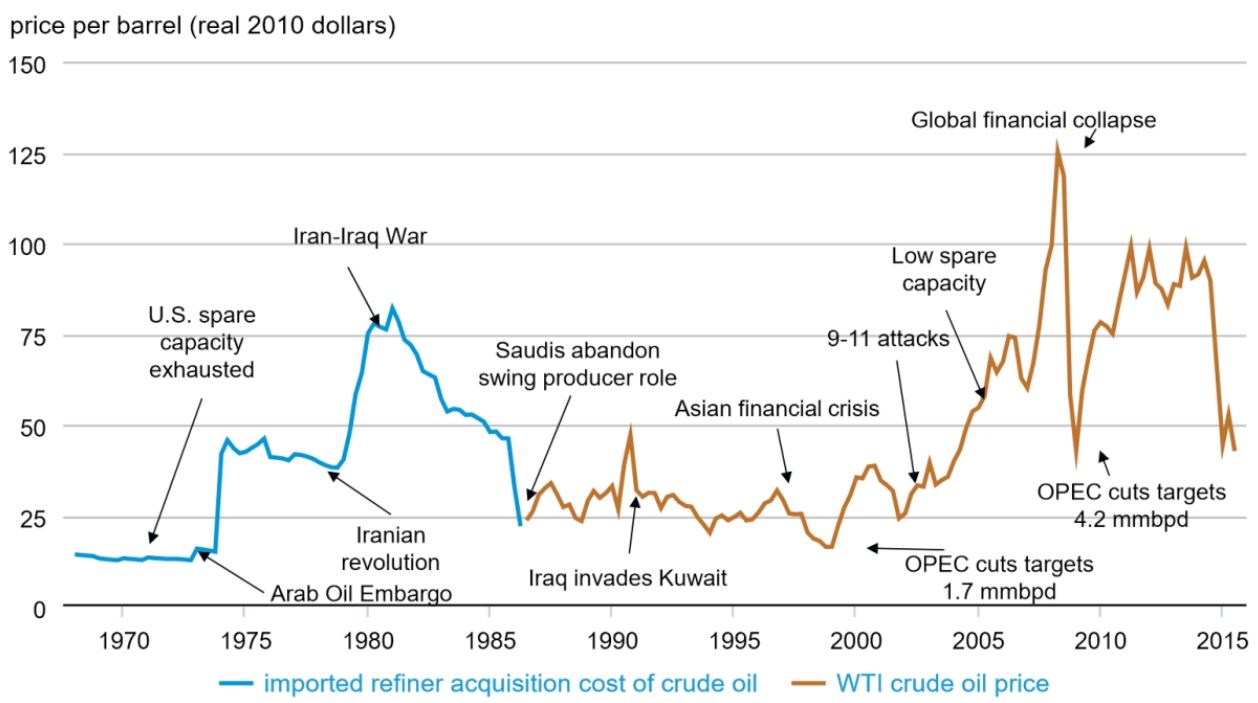

Source: U.S. Energy Information Administration, Thomson Reuters, October 2015.

Severe worldwide recession in 2008-2009 conspicuously reduced economic activity and demand for crude oil and petroleum products, thus lowering their prices until economies began to recover. Beside this, supply disruptions are a feature of world oil markets that cause substantial uncertainty and can immediately affect market prices. An example occurred in 2011 during the Arab Spring, when Libyan oil production dropped by over 1 million barrels per day relative to 2010 levels. In periods of low excess production capacity, it is more difficult to absorb a loss of supply without increases in prices (Levine et al. 2014; Kilian, 2009: 21; Bacon \& Kojima, 2008: 2-6). Following four years of relative stability at around $\$ 105$ per barrel, oil prices have declined sharply since June 2014 and are expected to remain low for a considerable period. West Texas Intermediate (WTI) Crude Oil is already trading at its lowest level since February 2009.

In the scope of global financial crisis, the uncertainty raise the importance of modelling oil price volatility. The remainder of this paper proceeds as follows. In the following sections, a brief summary of literature is given, then information about the methodology is introduced, and data set and empirical results are discussed. Finally, concluding remarks are presented. 


\section{Literature Review}

The complexity and importance of oil markets make them an important discussion topic for many studies. Economists have devoted great efforts towards developing methods to forecast price and volatility levels. All these studies proceed different type of theoretical and empirical analysis for understanding the formations of oil prices and markets.

Bacon and Kojima (2006 and 2008), analyzed oil market and prices with a very detailed economic and statistical methodology. In the Energy Sector Management Assistance Program (ESMAP) 2006 report dealt with higher oil price levels; and 2008 report focused on fluctuations around trends in oil prices. Alternatively, Kojima (2009) ascertained government politics against oil price volatility with the experience of fortynine developing countries and suggested different type of politics to control oil price volatility. Pirog (2005) analyzed the factors that have driven both demand and supply in the world oil market in the period 2003 through 2005. Kilian (2009) studied oil prices volatility with a historical perspective and presented the effect of price shocks on economic behalves. Mussa (2000) argued the effects of higher oil prices on global economy, financial markets with a historical perspective and dynamic policy suggestions. Arouri and Rault (2009) studied the influence of oil prices on stock markets with panel data analysis for Gulf Corporation Countries and they found that oil price increases have a positive impact on stock prices except Saudi Arabia. Alper and Torul (2009) investigated the relationship between oil prices and manufacturing sector for Turkey by using Vector AutoRegressive (VAR) estimations. They report that oil price increases do not significantly affect the manufacturing sector in aggregate terms, some sub-sectors are adversely affected. Arouri et al. (2011) investigate the six countries members of the Gulf Cooperation Council (GCC) from 2005 to 2010 and find the existence of significant return and volatility spillovers between world oil prices and GCC stock markets. Belkhouja and Boutahary (2011) argued that the long memory behavior of the crude oil absolute returns is not only explained by the existence of the long memory in the volatility but also by deterministic changes in the unconditional variance. Hasan and Ratti (2012) argue that oil price volatility influence stock prices through affecting expected cash flows and discount rates since oil is an input in production. Rentschler (2013) posits that the impacts of sudden changes in oil prices can have detrimental effects and repercussions throughout the economy, disturbing macro-indicators such as employment, trade balance, inflation and public accounts, as well as stock market prices and exchange rates.

Most academic research focuses on the effects of price levels, whether high or low, rather than volatility. Likewise, a few others examine the relation between oil prices and exchange rates or stock prices (indices). The main contribution of this paper to the relevant literature is to analyze the crude oil price volatility, rather than the effects of rising or falling oil prices, and to reveal the effects of global financial crisis on volatility. 


\section{Methodology}

It is often argued that financial time series are conditionally heteroskedastic. The presence of heteroskedasticity in financial time series arise when the homoskedasticity assumption is violated. Particularly studying with high frequency models like financial time series analysis requires to work with heteroskedastic models. Therefore, throughout modelling, postulating that the variance is not rigid in the sample period and it is variable, rustles up to have more coherent results (Baltagi, 2000: 375).

The basic statistical features of financial time series may be classified as leptokurtic distribution, volatility clustering, leverage effect-asymmetric information and co-movement process. The features mentioned above discloses the need for different type of conditional heteroskedastic models. In today's financial engineering techniques, there are more than six hundred derivative models of conditional heteroskedastic models. Nevertheless, basic type of them introduced by Engle (1982) as ARCH (AutoRegressive Conditional Heteroskedasticity) and Bollerslev (1986) as GARCH (Generalized AutoRegressive Conditional Heteroskedasticity) models. The importance of these models arises from their usage on portfolio risk and volatility analysis (Brooks, 2002: 439). Here, the basic definitions and theoretic properties of the models are discussed.

The basic idea of the ARCH models is that the mean corrected asset return model is serially uncorrelated, but dependent and the dependence of this model can be described by a simple quadratic function of its lagged values (Chatfield, 2003: 83). Specifically, a basic ARCH $(q)$ model can be described as follows:

$$
\sigma_{t}^{2}=w_{0}+\sum_{i=1}^{q} \alpha_{i} \varepsilon_{t-i}^{2}
$$

A generalized model of ARCH $(q)$ model with a AutoRegressive AR $(p)$ process gives the GARCH model. The GARCH $(p, q)$ model may be formalized with the equation below:

$$
\sigma_{t}^{2}=w_{0}+\sum_{i=1}^{q} \alpha_{i} \varepsilon_{t-i}^{2}+\sum_{j=1}^{p} \beta_{j} \sigma_{t-j}^{2}
$$

Concluding, the GARCH model enables to include the lagged values of $\varepsilon_{t}^{2}$ and $\sigma_{t}^{2}$ to the model process.

The ARCH literature has developed so rapidly. One recent development in the $\mathrm{ARCH}$ literature has focused on the power term by which the data is to be transformed. Ding et al. (1993) introduced a new class of ARCH model called The Generalized Asymmetric Power ARCH (APGARCH) model, which estimates the optimal power term. 
They also found that the absolute returns and their power transformations have a highly significant long-term memory property as the returns are highly correlated. The APGARCH model is presented in the following framework (Harris \& Sollis, 2003: 237-8):

$$
\sigma_{t}^{\delta}=w_{0}+\sum_{i=1}^{q} \alpha_{i}\left(\left|\varepsilon_{t-i}\right|-\gamma_{i} \varepsilon_{t-i}\right)^{\delta}+\sum_{j=1}^{p} \beta_{j} \sigma_{t-j}^{\delta}
$$

where $w_{0}$ is a constant parameter, $\varepsilon_{t}$ is the innovation process, $\sigma_{t}$ is the conditional standard deviation. Here $\alpha_{i}$ and $\beta_{j}$ are the standard ARCH and GARCH parameters, $\gamma_{i}$ is the leverage parameter and $\delta$ is the parameter for the power term. A positive (resp. negative) value of the $\gamma_{i}$ means that past negative (resp. positive) shocks have a deeper impact on current conditional volatility than past positive (resp. negative) shocks. Also, $w_{0}>0, \alpha_{i} \geq 0, \beta_{j} \geq 0, \delta \geq 0$ and $\left|\gamma_{i}\right| \leq 1$. In the APGARCH model, good news $\left(\varepsilon_{t-i}>0\right)$ and bad news $\left(\varepsilon_{t-i}<0\right)$ have different predictability for future volatility, because the conditional variance depends not only on the magnitude but also on the sign of $\varepsilon_{t}$.

Fractionally integrated processes, which are a subclass of long memory processes, have been investigated recently in volatility studies. Baillie et al. (1996) introduced the Fractionally Integrated Generalized AutoRegressive Conditional Heteroskedasticity (FIGARCH hereafter) process to recover the long memory observed in the volatility of financial return series, and the model also fills the gap between short and complete persistence. The FIGARCH model provides flexibility for capturing long memory in the conditional variance.

In contrast to an $I(0)$ time series in which shocks die out at an exponential rate, or an $I(1)$ series in which there is no mean reversion, shocks to an $I(d)$ time series with $0<d<1$ decay at a slow hyperbolic rate (Tang \& Shieh, 2006: 439). The FIGARCH $(p, d, q)$ can be expressed as follows (Baillie et al. 1996: 8):

$$
\left\{\begin{array}{l}
\varepsilon_{t}=z_{t} \sqrt{\sigma_{t}^{2}}, \varepsilon_{t} \mid \Omega_{t-1} \sim N\left(0, \sigma_{t}^{2}\right) \\
\sigma_{t}^{2}=w_{0}+\beta(L) \sigma_{t}^{2}+\left[1-\beta(L)-[1-\Phi(L)](1-L)^{d}\right] \varepsilon_{t}^{2}
\end{array}\right.
$$

where $\left\{z_{t}\right\}$ is a sequence of independent standard normal variables with variance $1,\left\{\sigma_{t}^{2}\right\}$ is a positive time dependent conditional variance defined as $\sigma_{t}^{2}=E\left(\varepsilon_{t}^{2} \mid \Omega_{t-1}\right)$ and $\Omega_{t-1}$ is the information set up to time $t$-1. Defining $v_{t} \equiv \varepsilon_{t}^{2}-\sigma_{t}^{2}$ the FIGARCH $(p, d, p)$ process may be rewritten as follows (Belkhouja \& Boutahary, 2011: 1108): 


$$
[1-\phi(L)](1-L)^{d} \varepsilon_{t}^{2}=w_{0}+[1-\beta(L)] v_{t}
$$

where $\phi(L) \equiv \phi_{1} L+\cdots+\phi_{q} L^{q}$ and $\beta(L) \equiv \beta_{1} L+\cdots+\beta_{p} L^{p}$. Here, $[1-\beta(L)]$ and $[1-\phi(L)]$ have all their roots outside the unit circle. The $v_{t}$ process can be interpreted as the innovations for the conditional variance and has zero mean serially uncorrelated. The fractional differencing operator $(1-L)^{d}$ with real $d$ is defined by (Hosking, 1981):

$$
(1-L)^{d}=\sum_{k=0}^{\infty} \delta_{k}(d) L^{k}, \delta_{k}(d)=\frac{k-1-d}{k} \delta_{k-1}(d), \delta_{0}(d)=1
$$

where $L$ is the lag operator and $d$ is the long memory parameter. We have a stationary long memory process when $0<d<1$. The FIGARCH model offers greater flexibility for modeling the conditional variance, as it accommodates the covariance stationary GARCH model for $d=0$ and the non-stationary IGARCH model for $d=1$. If $d=1$, the process has a unit root and thus a permanent shock effect.

Baillie et al. (1996) state that the impact of a shock on the conditional variance of the FIGARCH $(p, d, q)$ processes decrease at a hyperbolic rate when $0<d<1$. Hence, the long-term dynamics of the volatility is taken into account by the fractional integration parameter $d$, and the short-term dynamics is modeled through the traditional GARCH parameters.

\section{Data and Empirical Results}

This section presents empirical example involving the daily crude oil spot price (Dollars per Barrel) of West Texas Intermediate (WTI), which is used as a benchmark in oil pricing. The data used in the study is obtained from the Energy Information Administration (EIA) for the period January 3, 2005 and September 30, 2015 with 2704 observations. After analyzing the whole period, the sample is divided into two distinct periods: the crisis period (January 3, 2005 - May 29, 2009) and post-crisis period (June 1, 2009 - September 30, 2015). The reason why June 1, 2009 chosen is that the main impact of the global financial crisis is considered to be decrease. The returns are calculated by log return $r_{t}=\ln \left(p_{t} / p_{t-1}\right)$ of the closing prices. Table 1 presents the descriptive statistics for crude oil return series. 
Table: 1

Descriptive Statistics of Sample Data

\begin{tabular}{|c|c|c|c|}
\hline & $\begin{array}{c}\text { Whole Period } \\
\text { (January 3, 2005 - September 30, 2015) }\end{array}$ & $\begin{array}{c}\text { Crisis Period } \\
\text { (January 3, 2005 - May 29, 2009) }\end{array}$ & $\begin{array}{c}\text { Post-Crisis Period } \\
\text { (June 1, 2009-September 30, 2015) }\end{array}$ \\
\hline Observations & 2704 & 1106 & 1598 \\
\hline Mean & 0,000025 & 0,000393 & $-0,000228$ \\
\hline Minimum & $-0,128267$ & $-0,128267$ & $-0,111258$ \\
\hline Maximum & 0,164137 & 0,164137 & 0,098980 \\
\hline Standard Deviation & 0,023768 & 0,028572 & 0,019790 \\
\hline Skewness & 0,026381 & 0,050426 & $-0,069778$ \\
\hline Kurtosis & 8,081925 & 7,445409 & 6,096169 \\
\hline $\begin{array}{l}\text { Jarque Bera } \\
\text { (p-value) }\end{array}$ & $\begin{array}{c}2910,04 \\
(0,000)\end{array}$ & $\begin{array}{l}910,33 \\
(0,000)\end{array}$ & $\begin{array}{l}639,58 \\
(0,000)\end{array}$ \\
\hline $\begin{array}{l}\text { ARCH LM } \\
\text { (p-value) }\end{array}$ & $\begin{array}{l}188,24 \\
(0,000)\end{array}$ & $\begin{array}{c}71,53 \\
(0,000)\end{array}$ & $\begin{array}{c}87,43 \\
(0,000)\end{array}$ \\
\hline \multicolumn{4}{|c|}{ Unit Root Tests } \\
\hline ADF test & $-53,74$ & $-33,95$ & $-41,97$ \\
\hline PP test & $-53,71$ & $-34,12$ & $-41,95$ \\
\hline KPSS test & 0,05 & 0,09 & 0,04 \\
\hline
\end{tabular}

Notes: MacKinnon's critical value at the 1\% significance level for ADF and PP tests is -2,57 (without constant and trend), for KPSS test critical value is 0,21 (with constant and trend) at the 1\% significance level.

According to descriptive statistics, it is not surprising that the return series exhibit asymmetric and leptokurtic (fat tail) properties for all periods. The crude oil return series have positive (resp. negative) skewness for whole and crisis period (resp. post-crisis period) and the kurtosis exceeds three, indicating fat tails and leptokurtic distribution for all periods. Thus, the return series are not normally distributed. It is seen that the standard deviation (in other words volatility) in the crisis period is highest and in the post-crisis period fell conspicuously. Additionally, by Jarque-Bera statistics and corresponding pvalues, we reject the null hypothesis that returns are well approximated by the normal distribution. ARCH LM statistics highlight the existence of conditional heteroskedastic ARCH effect for all periods. The crude oil return series are subjected to three unit root tests to determine whether stationary I(0). The Augmented-Dickey-Fuller (ADF), PhillipsPeron (PP) and Kwiatkowski, Phillips, Schmidt, and Shin (KPSS) test statistics reject the hypothesis of a unit root at the $1 \%$ level of confidence.

As well as descriptive statistics, examining the crude oil return graph in Figure 2 shows the volatility clustering in several periods especially in the global crisis period. Volatility clustering which means that there are periods of large absolute changes tend to cluster together followed by periods of relatively small absolute changes. 
Figure: 2

Logarithmic Return Series for Crude Oil Prices (Jan. 3, 2005 - Sep. 30, 2015)

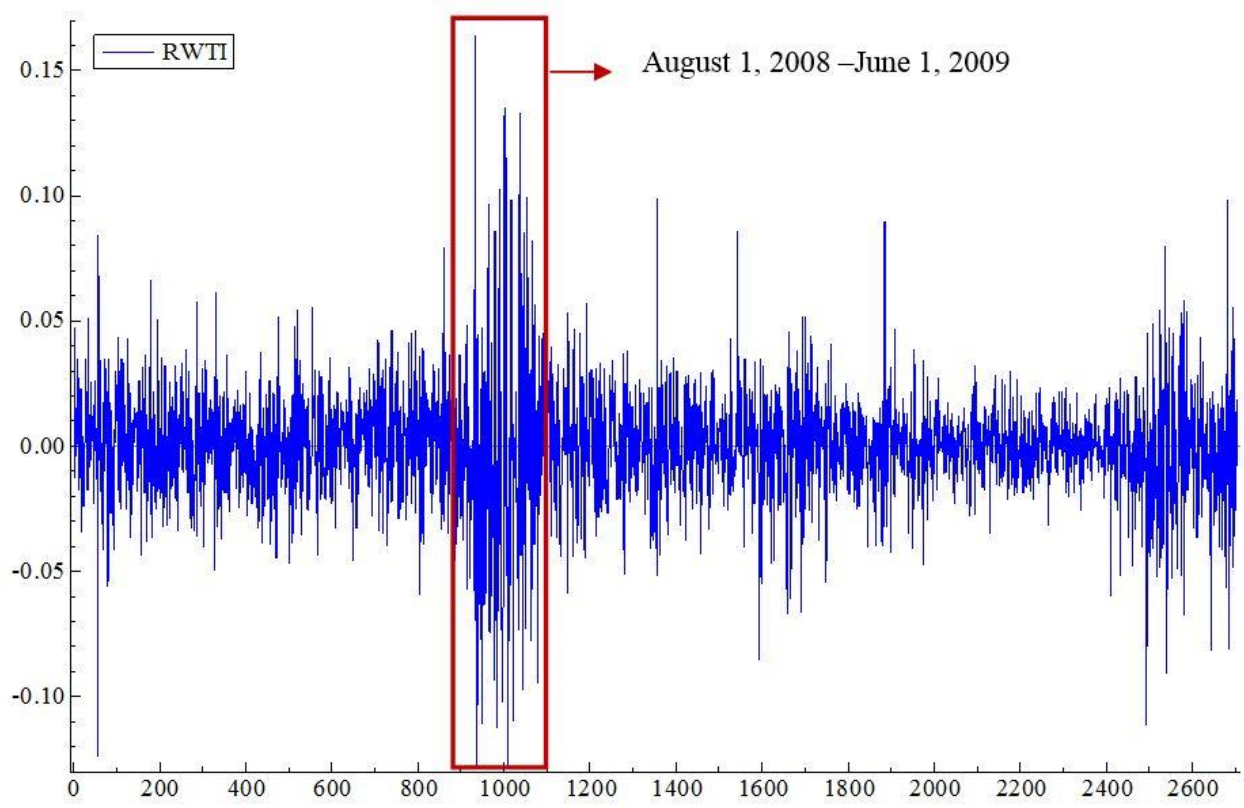

For the volatility analysis the GARCH, APGARCH, FIGARCH and FIAPGARCH models are performed. The reasons why these models selected are based on the content of the models. GARCH model is the basic type of variance modelling which also covers ARCH model. APGARCH model enables to determine the asymmetric and leverage effects and consequently the difference of the effects of good and bad news on oil markets. Finally modelling FIGARCH and FIAPGARCH, discloses the long memory effects and the long memory type asymmetry and leverage effect on oil prices.

GARCH-type models are estimated under Normal, Student-t, GED (Generalized Error Distribution) and Skewed Student-t distributions. The standard of model selection is based on in-sample diagnosis including Akaike Information Criterion (AIC), Schwarz Information Criterion (SIC), Shibata (SHI), Hannan-Quinn (HAQ), log-likelihood (LL) values, and Ljung-Box Q and Q2 statistics on standardized and squared standardized residuals respectively. Under every distribution, the model that has the lowest AIC, SIC, SHI and HAQ or highest LL values and passes the Q-tests simultaneously is adopted. In summary, ranking by AIC, SIC, SHI, HAQ and LL favors the Skewed Student-t (SkSt) specification with the first order lags in crude oil return series for the whole and post-crisis periods. While Table 3 (Crisis Period) reports the estimation results under Student-t (St) distribution, Table 2 (Whole Period) and Table 4 (Post-Crisis Period) reports the estimation results under Skewed Student-t (SkSt) distribution. To conserve space the 
results of the models with other distributions declined to present, but they are available upon request.

Table: 2

Whole Period Estimation Results (Jan. 3, 2005 - Sep. 30, 2015)

\begin{tabular}{|c|c|c|c|c|}
\hline & GARCH & APGARCH & FIGARCH & FIAPGARCH \\
\hline$\mu$ & $\begin{array}{l}0,00030 \\
(0,3853)\end{array}$ & $\begin{array}{c}0,00008 \\
(0,8050)\end{array}$ & $\begin{array}{l}0,00037 \\
(0,2732)\end{array}$ & $\begin{array}{l}0,00013 \\
(0,6967)\end{array}$ \\
\hline$\omega$ & $\begin{array}{l}0,00000 \\
(0,0425)\end{array}$ & $\begin{array}{l}0,00003 \\
(0,3263) \\
\end{array}$ & $\begin{array}{l}0,00000 \\
(0,1103)\end{array}$ & $\begin{array}{l}0,00003 \\
(0,4554) \\
\end{array}$ \\
\hline$\alpha$ & $\begin{array}{c}0,05437 \\
(0,0000)\end{array}$ & $\begin{array}{l}, 05203 \\
(0,0000)\end{array}$ & $\begin{array}{l}0,35212 \\
(0,0000)\end{array}$ & $\begin{array}{l}0,37367 \\
(0,0000)\end{array}$ \\
\hline$\beta$ & $\begin{array}{l}0,94231 \\
(0,0000)\end{array}$ & $\begin{array}{l}0,95047 \\
(0,0000)\end{array}$ & $\begin{array}{l}0,73745 \\
(0,0000)\end{array}$ & $\begin{array}{l}0,73337 \\
(0,0000)\end{array}$ \\
\hline$\gamma$ & - & $\begin{array}{l}0,46187 \\
(0,0006)\end{array}$ & - & $\begin{array}{l}0,37729 \\
(0,0044)\end{array}$ \\
\hline$\delta$ & - & $\begin{array}{l}1,34774 \\
(0,0000) \\
\end{array}$ & - & $\begin{array}{r}1,69441 \\
(0,0000) \\
\end{array}$ \\
\hline$\xi$ & $\begin{array}{c}-0,05911 \\
(0,0366)\end{array}$ & $\begin{array}{c}-0,06498 \\
(0,0213)\end{array}$ & $\begin{array}{c}-0,05501 \\
(0,0531)\end{array}$ & $\begin{array}{c}-0,06378 \\
(0,0240)\end{array}$ \\
\hline u & $\begin{array}{c}7,83888 \\
(0,0000)\end{array}$ & $\begin{array}{l}8,27954 \\
(0,0000)\end{array}$ & $\begin{array}{l}7,88141 \\
(0,0000)\end{array}$ & $\begin{array}{l}8,41979 \\
(0,0000)\end{array}$ \\
\hline$d$ & - & - & $\begin{array}{l}0,50788 \\
(0,0000)\end{array}$ & $\begin{array}{c}0,4761 \\
(0,0000)\end{array}$ \\
\hline LL & 6769,63 & 6783,22 & 6767,84 & 6779,68 \\
\hline AIC & $-5,00269$ & $-5,01126$ & $-5,00062$ & $-5,00790$ \\
\hline BIC & $-4,98959$ & $-4,99379$ & $-4,98534$ & $-4,98825$ \\
\hline \begin{tabular}{|l|} 
SHI \\
\end{tabular} & $-5,00270$ & $-5,01127$ & $-5,00064$ & $-5,00792$ \\
\hline HAQ & $-4,99765$ & $-5,00494$ & $-4,99509$ & $-5,00079$ \\
\hline $\mathrm{Q}(20)$ & $12,0745(0,913)$ & $10,6298(0,955)$ & $13,5287(0,854)$ & $11,7652(0,924)$ \\
\hline Q2(20) & $19,0383(0,389)$ & $20,8336(0,288)$ & $17,8066(0,468)$ & $18,3788(0,431)$ \\
\hline ARCH (5) & $1,5998(0,157)$ & $2,5005(0,290)$ & $1,5470(0,172)$ & $1,7521(0,119)$ \\
\hline
\end{tabular}

Note: The values in parentheses show the t-probability values. LL denotes Log-Likelihood, AIC, BIC, SHI and $H A Q$ denotes Akaike, Schwarz, Shibata and Hannan-Quinn Information Criteria, Q(20) andQ2(20) shows the Ljung-Box statistical values for autocorrelation existence of standardized and squared standardized error series, respectively.

As seen from Table 2 (Whole Period) below, the mean equation constant variables $(\mu)$ are positive but not significant whereas the variance equation constant variables $(w)$ are found positive for all models but significant only for GARCH model. The $\alpha$ and $\beta$ parameters which show the short and long memory effects alternately, found statistically significant for all models. In this respect, it is obvious that the shocks are effective on oil market prices and on their volatility. $\beta$ is close to 1 but significantly different from 1 for all models, which indicates a high degree of volatility persistence. The APGARCH and FIAPGARCH models include a leverage term $(\gamma)$ which allows positive and negative shocks of equal magnitude to elicit an unequal response from the market. The estimated coefficients are positive and statistically significant. This means that negative shocks lead to higher subsequent volatility than positive shocks. Also, the asymmetry parameters $(\xi)$ with SkSt distribution are negative and statistically significant.

The tail term $(v)$ is much larger for the APGARCH and FIAPGARCH models. This means that daily returns of crude oil price display a much larger kurtosis and exhibit 
fatter tails. Besides, when taking into account the global financial crisis the evidences show that fat-tail phenomenon is strong because the student or tail terms $(v)$ are significantly different from zero under SkSt distribution.

The coefficients of the function parameter $(\delta)$ of APGARCH and FIAPGARCH models are statistically significant and close to value 1 for APGARCH and 2 for FIAPGARCH model. This demonstrates that modelling variance is more appropriate rather than modelling standard deviation with APGARCH model. In addition to this, the coefficient of fractional integer parameter $(d)$ of FIGARCH and FIAPGARCH models, found statistically significant and also between $0<d<1$. The finding of $d$ parameters coefficients that close to value 0.50 , show up the effectiveness of long memory effects on oil market prices.

Table: 3

Crisis Period Estimation Results (Jan. 3, 2005 - May. 29, 2009)

\begin{tabular}{|c|c|c|c|c|}
\hline & GARCH & APGARCH & FIGARCH & FIAPGARCH \\
\hline$\mu$ & $\begin{array}{l}0,00134 \\
(0,0411)\end{array}$ & $\begin{array}{l}0,00103 \\
(0,1206) \\
\end{array}$ & $\begin{array}{l}0,00140 \\
(0,0340)\end{array}$ & $\begin{array}{l}0,00108 \\
(0,1023) \\
\end{array}$ \\
\hline$\omega$ & $\begin{array}{c}0,00001 \\
(0,0290) \\
\end{array}$ & $\begin{array}{l}0,00003 \\
(0,5591) \\
\end{array}$ & $\begin{array}{c}0,00002 \\
(0,1037) \\
\end{array}$ & $\begin{array}{l}0,00008 \\
(0,5359) \\
\end{array}$ \\
\hline$\alpha$ & $\begin{array}{l}0,06551 \\
(0,0005)\end{array}$ & $\begin{array}{l}0,05960 \\
(0,0039)\end{array}$ & $\begin{array}{l}0,24246 \\
(0,0067)\end{array}$ & $\begin{array}{l}0,28886 \\
(0,0029)\end{array}$ \\
\hline$\beta$ & $\begin{array}{l}0,92138 \\
(0,0000)\end{array}$ & $\begin{array}{l}0,92854 \\
(0,0000)\end{array}$ & $\begin{array}{l}0,64950 \\
(0,0000)\end{array}$ & $\begin{array}{l}0,66819 \\
(0,0000)\end{array}$ \\
\hline$\gamma$ & - & $\begin{array}{l}0,32668 \\
(0,1867)\end{array}$ & - & $\begin{array}{l}0,31945 \\
(0,1200)\end{array}$ \\
\hline$\delta$ & - & $\begin{array}{l}1,68758 \\
(0,0010) \\
\end{array}$ & - & $\begin{array}{l}1,66714 \\
(0,0000) \\
\end{array}$ \\
\hline$d$ & - & - & $\begin{array}{c}0,48887 \\
(0,0002) \\
\end{array}$ & $\begin{array}{l}0,47052 \\
(0,0006) \\
\end{array}$ \\
\hline LL & 2580,08 & 2583,05 & 2578,93 & 2582,34 \\
\hline AIC & $-4,65656$ & $-4,65831$ & $-4,65268$ & $-4,65523$ \\
\hline BIC & $-4,63392$ & $-4,62661$ & $-4,62551$ & $-4,61900$ \\
\hline SHI & $-4,65660$ & $-4,65839$ & $-4,65274$ & $-4,65533$ \\
\hline HAQ & $-4,64800$ & $-4,64632$ & $-4,64241$ & $-4,64153$ \\
\hline $\mathrm{Q}(20)$ & $13,3296(0,863)$ & $12,2823(0,906)$ & $13,0978(0,873)$ & $12,0374(0,915)$ \\
\hline Q2(20) & $9,4964(0,947)$ & $9,6432(0,943)$ & $9,4379(0,949)$ & $10,0142(0,931)$ \\
\hline $\begin{array}{l}\mathrm{ARCH}(5) \\
\end{array}$ & $0,7948(0,553)$ & $0,9033(0,478)$ & $0,7124(0,614)$ & $0,8323(0,527)$ \\
\hline
\end{tabular}

Note: The values in parentheses show the t-probability values. LL denotes Log-Likelihood, AIC, BIC, SHI and $H A Q$ denotes Akaike, Schwarz, Shibata and Hannan-Quinn Information Criteria, Q(20) and Q2(20) shows the Ljung-Box statistical values for autocorrelation existence of standardized and squared standardized error series, respectively.

As seen from Table 3 (Crisis Period) below, approximately similar and statistically significant coefficients were obtained under Student-t (St) distribution. The mean equation constant variables $(\mu)$ are positive but significant only for GARCH and FIGARCH models. The variance equation constant variables $(w)$ are found positive for all models but significant only for GARCH model, as Table 2. The positive and statistically significant leverage terms $(\gamma)$ for the APGARCH and FIAPGARCH models mean that negative shocks lead to higher subsequent volatility than positive shocks. 
The coefficients of the function parameter $(\delta)$ of APGARCH and FIAPGARCH models are statistically significant and close to value 2 . This demonstrates that modelling standard deviation is more appropriate. In addition to this, the coefficient of fractional integer parameter $(d)$ of FIGARCH and FIAPGARCH models, found statistically significant and also between $0<d<1$. The finding of $d$ parameters coefficients that close to value 0.50 , show up the effectiveness of long memory effects on oil market prices for the crisis period.

Table: 4

Post-Crisis Period Estimation Results (Jun. 1, 2009 - Sep. 30, 2015)

\begin{tabular}{|c|c|c|c|c|}
\hline & GARCH & APGARCH & FIGARCH & FIAPGARCH \\
\hline$\mu$ & $\begin{array}{l}0,00009 \\
(0,8125) \\
\end{array}$ & $\begin{array}{c}-0,00034 \\
(0,2960) \\
\end{array}$ & $\begin{array}{l}-0,00006 \\
(0,8750) \\
\end{array}$ & $\begin{array}{l}0,00028 \\
(0,4633) \\
\end{array}$ \\
\hline$\omega$ & $\begin{array}{l}0,00000 \\
(0,1478) \\
\end{array}$ & $\begin{array}{l}0,00006 \\
(0,4387) \\
\end{array}$ & $\begin{array}{l}0,00000 \\
(0,1214) \\
\end{array}$ & $\begin{array}{l}0,00000 \\
(0,9372)\end{array}$ \\
\hline$\alpha$ & $\begin{array}{l}0,05050 \\
(0,0004)\end{array}$ & $\begin{array}{l}0,03690 \\
(0,0000) \\
\end{array}$ & $\begin{array}{l}0,50847 \\
(0,0000)\end{array}$ & $\begin{array}{l}0,55098 \\
(0,0000) \\
\end{array}$ \\
\hline$\beta$ & $\begin{array}{l}0,94582 \\
(0,0000)\end{array}$ & $\begin{array}{l}0,95853 \\
(0,0000)\end{array}$ & $\begin{array}{l}0,81971 \\
(0,0000)\end{array}$ & $\begin{array}{l}0,77532 \\
(0,0000)\end{array}$ \\
\hline$\gamma$ & - & $\begin{array}{l}0,99993 \\
(0,0006) \\
\end{array}$ & - & $\begin{array}{l}0,35087 \\
(0,0364) \\
\end{array}$ \\
\hline$\delta$ & - & $\begin{array}{l}1,23155 \\
(0,0000) \\
\end{array}$ & - & $\begin{array}{l}2,02282 \\
(0,0000) \\
\end{array}$ \\
\hline$\xi$ & $\begin{array}{c}-0,08916 \\
(0,0105) \\
\end{array}$ & $\begin{array}{c}-0,09369 \\
(0,0213)\end{array}$ & $\begin{array}{l}-0,09002 \\
(0,0112)\end{array}$ & $\begin{array}{l}-0,09627 \\
(0,0071) \\
\end{array}$ \\
\hline$v$ & $\begin{array}{l}6,81461 \\
(0,0000)\end{array}$ & $\begin{array}{l}7,65564 \\
(0,0000) \\
\end{array}$ & $\begin{array}{l}6,99255 \\
(0,0000)\end{array}$ & $\begin{array}{l}7,34616 \\
(0,0000) \\
\end{array}$ \\
\hline d & - & - & $\begin{array}{l}0,48617 \\
(0,0000)\end{array}$ & $\begin{array}{l}0,36781 \\
(0,0003) \\
\end{array}$ \\
\hline LL & 4194,97 & 4207,14 & 4198,68 & 4207,25 \\
\hline AIC & $-5,24277$ & $-5,25550$ & $-5,24616$ & $\begin{array}{l}-5,25438 \\
\end{array}$ \\
\hline BIC & $-5,22258$ & $\begin{array}{c}-5,22858 \\
\end{array}$ & $-5,22261$ & $-5,22410$ \\
\hline SHI & $-5,24280$ & $-5,25555$ & $-5,24620$ & $-5,25444$ \\
\hline HAQ & $-5,23527$ & $-5,24550$ & $-5,23742$ & $-5,24313$ \\
\hline $\mathrm{Q}(20)$ & $11,7051(0,926)$ & $10,2174(0,964)$ & $12,4002(0,902)$ & $10,9121(0,948)$ \\
\hline Q2(20) & $19,1241(0,384)$ & $23,7750(0,163)$ & $15,1337(0,653)$ & $15,7009(0,613)$ \\
\hline ARCH (5) & $1,6447(0,145)$ & $2,1658(0,055)$ & $1,0873(0,365)$ & $0,9182(0,468)$ \\
\hline
\end{tabular}

Note: The values in parentheses show the t-probability values. LL denotes Log-Likelihood, AIC, BIC, SHI and HAQ denotes Akaike, Schwarz, Shibata and Hannan-Quinn Information Criteria, Q(20) and Q2(20) shows the Ljung-Box statistical values for autocorrelation existence of standardized and squared standardized error series, respectively.

As seen from Table 4 (Post-Crisis Period) below, the main parameters similar to Table 2 and statistically significant. The mean and variance equations constant variables ( $\mu$ and $w$ respectively) are not significant. $\beta$ parameter is close to 1 which indicates a high degree of volatility persistence. The leverage term $(\gamma)$ coefficients for APGARCH and FIAPGARCH models were positive which means that negative shocks lead to higher subsequent volatility than positive shocks (asymmetry in the conditional variance). Also, the asymmetry parameters $(\xi)$ with SkSt distribution are negative and statistically significant. 
The tail term (v) is lower for the APGARCH and FIAPGARCH models than discussed in Table 2 (Whole Period). However, for the post-crisis period, the tail term (U) is lower than whole period which means that daily returns of crude oil price display a much smaller kurtosis and exhibit thinner tails after global financial crisis.

For the post-crisis period, again the coefficients of the function parameter $(\delta)$ of APGARCH and FIAPGARCH models are statistically significant and close to value 1 for APGARCH and 2 for FIAPGARCH model. This demonstrates that modelling variance with FIGARCH model, and modelling standard deviation with APGARCH model is more appropriate. In addition to this, the coefficient of fractional integer parameter $(d)$ of FIGARCH and FIAPGARCH models, found statistically significant and close to value 0.50 , show up the effectiveness of long memory effects on oil market prices.

\section{Concluding Remarks}

The purpose of this study is to examine the comparative performance of volatility models and to reveal the effects of global financial crisis on volatility by using daily returns of crude oil price. The results of models highlight that oil prices are best fit by APGARCH and FIAPGARCH models with Skewed Student- $t$ (SkSt) distribution for whole and post-crisis periods, and by APGARCH model with Student- $t(S t)$ distribution for the crisis period. Furthermore, when considering the global financial crisis, the results show that the crude oil prices are characterized by high volatilities and have long memory effects, as expected.

As seen from empirical results, crude oil price returns have a high degree of volatility persistence, negative shocks lead to higher subsequent volatility than positive shocks. Based on the appropriate model selection criteria, the asymmetric GARCH models (APGARCH and FIAPGARCH) appear superior to the symmetric ones in dealing with oil price volatility. This finding indicates evidence of leverage effects in the oil market and ignoring these effects in oil price modelling will lead to serious biases and misleading results.

China is the second largest importer of oil in the world, so the slowdown in China has resulted in lower global growth and hence, a decreased demand for oil. In the context of recent oil price movement, factors contributing to oil price volatility are complex and inter-related. Global growth is directly linked to the crude oil prices. Oil price changes in a volatile market environment are less useful to forecast GDP growth. Oil price volatility both increases unemployment and inflation, and decreases economic growth. Several lessons emerge from the recent oil price episode. One is to prepare for the unexpected changes about the speed and the magnitude of oil prices. Equally important, high and volatile energy prices threaten to deepen energy poverty. 
Events since 2004 have shown that policy reversal is common. Moving from ad hoc pricing to market-based automatic price adjustment mechanisms can be an important step in making the downstream petroleum sector more efficient. Policy to reduce price volatility and its associated adverse macroeconomic effects must therefore encompass both supply-side (policy should be the stabilization of oil supply) and demand-side (policy should prioritize strategies that reduce oil dependency) solutions. A combination of supply-side and demand-side policies aimed to minimize short-term price volatility and promote market stability is vital. It could be suggested that analyzing of the impact of sudden changes or structural breaks in volatility persistence for further studies.

\section{References}

Alper, C.E. \& O. Torul (2009), “Asymmetric Effects of Oil Prices on Manufacturing Sector in Turkey”, IAEE International Conference in Istanbul, 1-22.

Arouri M. \& A. Lahiani \& D.K. Nguyen (2011), "Return and Volatility Transmission between World Oil Prices and Stock Markets of the GCC Countries", Economic Modelling, 28(4), $1815-1825$.

Arouri, M.E.H. \& C. Rault (2009), "On the Influence of Oil Prices on Stock Markets: Evidence from Panel Analysis in Gulf Corporation Countries", Economic Research Forum Reports, ERF Conference, Egypt, 1-19.

Bacon, R. \& M. Kojima (2006), "Coping with Higher Oil Prices”, Energy Sector Management Assistance Programme Report, The World Bank Group, USA, 1-256.

Bacon, R. \& M. Kojima (2008), "Coping with Oil Prices Volatility”, Energy Sector Management Assistance Programme Report, The World Bank Group, USA, 1-174.

Baillie, R.T. \& T. Bollerslev \& H.O. Mikkelsen (1996), "Fractionally Integrated Generalized AutoRegressive Conditional Heteroscedasticity”, Journal of Econometrics, 74, 3-30.

Baltagi, H.B. (2000), Econometrics, Springer Press, Fourth Edition, USA.

Belkhouja, M. \& M. Boutahary (2011), "Modeling volatility with time-varying FIGARCH models", Economic Modelling, 28, 1106-1116.

Bollerslev, T. (1986), “Generalised Autoregressive Conditional Heteroskedasticity”, Journal of Econometrics, 31, 307-327.

Brooks, C. (2002), Introductory Econometrics for Finance, Cambridge University Press, UK.

Castillo, P. \& C. Montoro \& V. Tuesta (2010), "Inflation, oil price volatility and monetary Policy", Banco Central de Reserva del Peru Working Papers, No. 2010-002.

Chatfield, C. (2003), The Analysis of Time Series: An Introduction, Chapman \& Hall/CRC Publishing, Sixth Edition, USA.

Ding, Z. \& C.W.J. Granger \& R.F. Engle (1993), “A Long Memory Property of Stock Market Returns and A New Model", Journal of Empirical Finance, 1, 83-106.

Engle, R.F. (1982), “Autoregressive Conditional Heteroscedasticity with Estimates of the Variance of United Kingdom Inflation", Econometrica, 50(4), 987-1007.

Federer, J.P. (1996), "Oil price volatility and the macroeconomy”, Journal of Macroeconomics, 18(1), 1-26. 
Harris, R. \& R. Sollis (2003), Applied Time Series Modelling and Forecasting, John Wiley\&Sons Inc., USA.

Hasan, M.Z. \& R.A. Ratti (2012), "Oil price shocks and volatility in Australian stock returns", Global Accounting, Finance and Economics Conference, Melbourne, VIC, 20-21 February.

Hosking, J.R.M. (1981), "Fractional differencing”, Biometrika, 68, 165-176.

International Energy Agency (2004), Analysis of the Impact of High Oil Prices on the Global Economy, <http://www.iea.org/papers/2004/high_oil_prices.pdf>, 20 June 2015.

Kilian, L. (2009), "Oil Prices Volatility: Origins and Effects, University of Michigan and CEPR", World Trade Organization Working Paper Series, USA, 1-34.

Kojima, M. (2009), "Government Response to Oil Price Volatility”, Extractive Industries for Development Series, No: 10, World Bank, USA, 1-102.

Le, D.T. (2015), "Ex-ante Determinants of Volatility in the Crude Oil Market", International Journal of Financial Research, 6(1), 1-13.

Levine, S. \& G. Taylor \& D. Arthur \& M. Tolleth (2014), Understanding Crude Oil and Product Markets, American Petroleum Institute.

Mussa, M. (2000), The Impact of Higher Oil Prices on the Global Economy, IMF Research Department, < http://www.imf.org/external/pubs/ft/oil/2000/>, 27 May 2015.

Pirog, R. (2005), "World Oil Demand and Its Effects on Oil Prices", CRS Report for Congress, Congressional Research Service, The Library of Congress, USA, No: RL32530.

Rentschler, J.E. (2013), “Oil Price Volatility, Economic Growth and the Hedging Role of Renewable Energy”, Policy Research Working Paper Series 6603, The World Bank.

Tang, T. \& S.J. Shieh (2006), "Long Memory in Stock Index Futures Markets: A Value-At-Risk Approach", Physica A, 366, 437-448.

UNDP / ESMAP (2005), The Impact of Higher Oil Prices on Low Income Countries and on the Poor, The International Bank of Reconstruction and Development/The World Bank Group ESMAP Reports, USA, 1-58.

Yan, L. (2012), “Analysis of the International Oil Price Fluctuations and Its Influencing Factors", American Journal of Industrial and Business Management, 2, 39-46. 
Ural, M. (2016), "Modelling Crude Oil Price Volatility and the Effects of Global Financial Crisis", Sosyoekonomi, Vol. 24(29), 167-181. 